\title{
Determination of Ethylenediaminetetra-acetic Acid in Foods by Colorimetry
}

\author{
Takashi Hamano*, Yukimasa Mitsuhashi ${ }^{*}$, Susumu Yamamoto* \\ Yukio Matsuki* ${ }^{*}$ Yasuhide Tonogai ${ }^{* *}$, Keizo Nakamura**, \\ and Yoshio ITo** \\ ${ }^{*}$ Public Health Research Institute of Kobe City, \\ Minatozimanaka-machi, Kobe 650 \\ ${ }^{* *}$ National Institute of Hygienic Science, Osaka Branch, \\ Hoenzaka, Osaka 540
}

\begin{abstract}
A method is described for the determination of ethylenediaminetetra-acetic acid (EDTA) and its metal chelates in foods. The principle of the method is that free copper ion $\left(\mathrm{Cu}^{2+}\right)$ reacts with bathocuproine but EDTA-Cu does not under definite condition. Food samples were homogenized with $0.1 \mathrm{M} \mathrm{NaOH}$, then subjected to equilibrium dialysis against $0.02 \mathrm{M}$ $\mathrm{NaOH} . \mathrm{EDTA}$ and its metal chelates in the dialyzate were converted into EDTA-Cu at $\mathrm{pH} 2.5$ by the addition of $\mathrm{CuSO}_{4}$. This solution was then divided into two portions of equal volume. One portion was subjected to assay of free $\mathrm{Cu}^{2+}$, and the other to assay of total (the sum of free and chelated) $\mathrm{Cu}^{2+}$. EDTA was calculated from the difference between the absorbances $(477 \mathrm{~nm})$ obtained with free and total $\mathrm{Cu}^{2+}$. Analyses of several foods with EDTA-Ca added showed the recovery of $88.7 \sim 99.4 \%$ for $50 \mu \mathrm{g} / \mathrm{g}$ and $92.7 \sim 99.9 \%$ for $250 \mu \mathrm{g} / \mathrm{g}$. Food ingredients such as organic acids, proteins, amino acids, peptides, phenolic compounds and emulsifying agents were without interferences.
\end{abstract}

Ethylenediaminetetra-acetic acid (EDTA), as its disodium or calcium disodium salt, is frequently used in foods such as mayonnaise, salad dressing and canned crab meat. The primary reason for use of EDTA is its sequestering effect on contaminating metal ions. In 1983, The Ministry of Health and Welfare of Japan permitted the use of EDTA as an antioxidant in commercial foods with maximal level of $250 \mu \mathrm{g} / \mathrm{g}$ for canned foods. Consequently, a simple and reliable method is required for routine inspection of EDTA.

Previous methods for the determination of EDTA have involved gas chromatographic ${ }^{1)}$ and high-performance liquid chromatographic ${ }^{2)}$ procedures. These methods, however, require elaborate derivatization step or the check of column efficiency at intervals for retaining their best performance. We therefore have sought for an alternative method.

In the literatures, $\mathrm{Cu}^{2+}$ in alcoholic beverage has been determined by simple colorimetry following the formation of a chromophore by reaction with a specific reagent ${ }^{3)}$. Free $\mathrm{Cu}^{2+}$ reacts with such reagent but EDTA-Cu does not under definite conditions. We now report the simple colorimetric method for the determination of EDTA in foods by adopting the above reaction mechanism.

\section{Materials and Method}

\section{Food samples}

Mayonnaise, salad dressing and canned foods were purchased from local outlets in Kobe City. Solid foods were minced into pieces less than $2 \mathrm{~mm}$ in length and width for extraction of EDTA.

\section{Reagents}

Bathocuproine, EDTA-2 $\mathrm{Na}$ and several metal chelates of EDTA were obtained from Wako Pure Chemicals. Cellophane tubing (36/32) for dialysis was also from Wako Pure Chemicals. 
All other reagents were of analytical grade.

\section{Preparation of food extract}

Food sample $(10 \sim 20 \mathrm{~g})$ was homogenized with $30 \mathrm{~m} l$ of $0.1 \mathrm{M} \mathrm{NaOH}$ containing $10 \%$ (w/w) $\mathrm{NaCl}$ to make $50 \mathrm{~m} l$. The homogenate $(25 \mathrm{ml})$ was introduced into a cellophane tubing of which one end had been closed. Af ter the other end was closed, it was subjected to equilibrium dialysis against $175 \mathrm{ml}$ of $0.02 \mathrm{M} \mathrm{NaOH}$ for $15 \mathrm{~h}$ at $38^{\circ} \mathrm{C}$. The dialyzate was referred to as extract solution.

\section{Assay}

The extract solution $(40 \mathrm{~m} l)$ was measured into a $100-\mathrm{m} l$ beaker. After adjusting the $\mathrm{pH}$ to about 2.5 with $0.5 \mathrm{M} \mathrm{HCl}, 4 \mathrm{ml}$ of $0.1 \mathrm{mM}$ $\mathrm{CuSO}_{4}$ was added to the solution in order to form $\mathrm{EDTA}-\mathrm{Cu}$, and then the volume was made to $50 \mathrm{~m} l$ with deionized water. This solution was divided into two portions of equal volume (25 $\mathrm{m} l$ each). One portion was introduced into a $100-\mathrm{m} l$ separatory funnel containing $5 \mathrm{~m} l$ of $0.4 \mathrm{M}$ potassium phosphate buffer ( $\mathrm{pH} 7.0$ ). After the addition of $3 \mathrm{ml}$ of $10 \mathrm{mM}$ ascorbic acid, $5 \mathrm{~m} l$ of color producing reagent which consisted of $40 \mathrm{mg}$ bathocuproine in $100 \mathrm{ml}$ of chloroform was also added. After the funnel had been shaken on a mechanical shaker for $10 \mathrm{~min}$, the chloroform layer was taken for measuring the absorbance at $477 \mathrm{~nm}$. The absorbance obtained corresponded to free $\mathrm{Cu}^{2+}$ that had not participate in chelate formation with EDTA.

The other portion was treated in the same manner as above, except that $0.4 \mathrm{M}$ Tris- $\mathrm{HCl}$ buffer ( $\mathrm{pH} 8.5$ ) containing $1 \mathrm{mM} \mathrm{CoCl}_{2}$ replaced the phosphate buffer. The absorbance obtained corresponded to total (the sum of free and chelated) $\mathrm{Cu}^{2+}$. EDTA content was then calculated from the difference between the absorbances obtained with free and total $\mathrm{Cu}^{2+}$ by means of a calibration curve.

\section{Results and Discussion}

\section{Establishment of reaction conditions}

It was shown that color development reaction of $\mathrm{Cu}^{2+}$ with bathocuproine should be done in the $\mathrm{pH}$ range of 4 to $10^{33}$. We have therefore sought the conditions where EDTA-Cu does not react with bathocuproine within the above $\mathrm{pH}$ range. As shown in Fig. 1, EDTA-Cu did not react with bathocuproine in the $\mathrm{pH}$ range of 6.5 to 7.5 in the presence of $\mathrm{Zn}^{2+}$. EDTA-Cu reacted with this reagent to some extent even at $\mathrm{pH} 7.0$ when potassium phosphate buffer was replaced with other buffers such as Tris- $\mathrm{HCl}$ or acetate buffer (data not shown). Accordingly, we selected potassium phosphate buffer $(\mathrm{pH}$ 7.0) for assay of free $\mathrm{Cu}^{2+}$.

Next, in order to assay total $\mathrm{Cu}^{2+}$, the condition must be found where the complete reaction of EDTA-Cu with bathocuproine took place as well as free $\mathrm{Cu}^{2+}$. It follows from the results in Fig. 2 that reaction $\mathrm{pH}$ gave a great effect on the reaction of EDTA-Cu with bathocuproine. When the reaction of EDTA-Cu with this reagent was carried out below $\mathrm{pH} 6.5$, the complete reaction was not achieved even in the presence of foreign metal ion $\left(\mathrm{Co}^{2+}\right)$. In contrast, the reaction of $\mathrm{EDTA}-\mathrm{Cu}$ with bathocuproine was almost stoichiometric when the reaction was done above $\mathrm{pH} 8.0$ in the presence of $\mathrm{Co}^{2+}$. The use of other metal ions instead of $\mathrm{Co}^{2+}$ resulted in incomplete reaction of EDTA-Cu with bathocuproine (Table 1). These results suggest the prerequisite of $\mathrm{Co}^{2+}$ for complete reaction of $\mathrm{EDTA}-\mathrm{Cu}$ with bathocup-

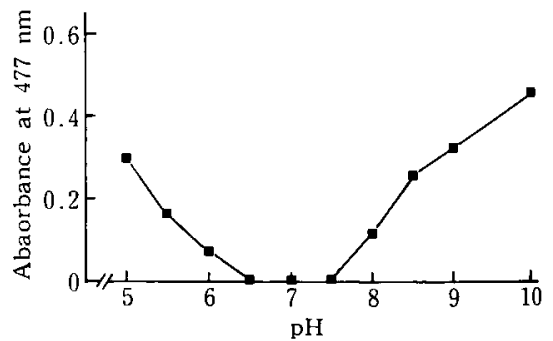

Fig. 1 Reaction of EDTA-Cu with bathocuproine as the function of $\mathrm{pH}$

EDTA-Cu $(0.2 \mu \mathrm{mol})$, dissolved in buffers with different $\mathrm{pH}$, was reacted with bathocuproine in the presence of $\mathrm{Zn}^{2+}(1 \mu \mathrm{mol})$. Buffers used were as follows: $0.1 \mathrm{M}$ acetate ( $\mathrm{pH} 5 \sim 6), 0.1 \mathrm{M}$ potassium phoshate $(\mathrm{pH} 6$ $\sim 7.5), 0.1 \mathrm{M}$ Tris- $\mathrm{HCl} \quad(\mathrm{pH} 7.5 \sim 9), 0.1 \mathrm{M}$ carbonate $(\mathrm{pH} 9 \sim 10)$. 


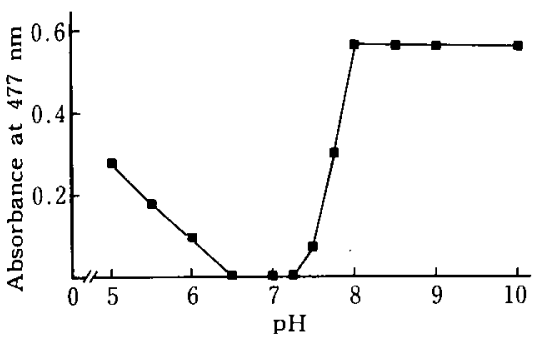

Fig. 2 Reaction of EDTA-Cu with bathocuproine in the presence of $\mathrm{Co}^{2+}$ as the function of $\mathrm{pH}$

EDTA-Cu $(0.2 \mu \mathrm{mol})$, dissolved in buffers with different $\mathrm{pH}$, was reacted with bathocuproine in the presence of $\mathrm{CoCl}_{2}(2 \mu \mathrm{mol})$. Buffers used were as follows : $0.1 \mathrm{M}$ acetate ( $\mathrm{pH}$ 5 6), $0.1 \mathrm{M}$ potassium phosphate ( $\mathrm{pH}$ 6 7.5), $0.1 \mathrm{M}$ Tris-HCl (pH 7.5 9), $0.1 \mathrm{M}$ carbonate $(\mathrm{pH} 9 \sim 10)$. The optical intensity of equimolar $\mathrm{CuSO}_{4}(0.2 \mu \mathrm{mol})$ was 0.56 .

Table 1 Reactivity of EDTA-Cu toward bathocuproine in the presence of foreign metal ion

\begin{tabular}{cc}
\hline \hline Metal ion & Absorbance at $477 \mathrm{~nm}$ \\
\hline $\mathrm{Co}^{2+}$ & 0.56 \\
$\mathrm{Sn}^{2+}$ & 0.26 \\
$\mathrm{Zn}^{2+}$ & 0.23 \\
$\mathrm{~Pb}^{2+}$ & 0.29 \\
\hline
\end{tabular}

Twenty $\mathrm{m} l$ of EDTA-Cu solution $(10 \mu \mathrm{M})$ was reacted with bathocuproine at $\mathrm{pH} 8.5$ using Tris- $\mathrm{HCl}$ buffer $(0.1 \mathrm{M})$ in the presence of foreign metal ions indicated. The amount of each metal ion used was $1 \mu \mathrm{mol}$. The absorbance of equimolar $\mathrm{CuSO}_{4}(0.2 \mu \mathrm{mol})$ was 0.56 .

roine. The use of $\mathrm{CoCl}_{2}$ for assay of total $\mathrm{Cu}^{2+}$ is reasonable because its presence did not interfere with $\mathrm{Cu}^{2+}$-bathocuproine reaction and its content in commercial foods could be negligible. Accordingly, Tris- $\mathrm{HCl}$ buffer containing $\mathrm{CoCl}_{2}$ was adopted for assay of total $\mathrm{Cu}^{2+}$.

Whether the optical intensities obtained at $\mathrm{pH} 7.0$ and $\mathrm{pH} 8.5$ in $\mathrm{Cu}^{2+}$-bathocuproine reaction were indentical was also critical for successful application of the present method for determination of EDTA. Fortunately, the optical intensity was constant in the $\mathrm{pH}$ range of 4 to 10 , and independent of component of buffers used (data not shown).

\section{Calibration curve}

A series of standard EDTA solution, prepared by dissolving EDTA-2 $\mathrm{Na}$ in deionized water, were subjected to assay of both free and total $\mathrm{Cu}^{2+}$. Then, the difference between the absorbance at $477 \mathrm{~nm}$ obtained by both assays was plotted against the amount of EDTA (as calcium disodium salt). The straight line fitting to 5 points had a slope of 0.98 and an intercept of 0.02 with a correlation coefficient of 0.996 . The lowest level for linearity was $0.374 \mu \mathrm{g} / \mathrm{ml}$. Therefore, the present method had a minimum quantitative level of about $7 \mu \mathrm{g} / \mathrm{g}$ when $10 \mathrm{~g}$ of sample was extracted and diluted to $200 \mathrm{~m} l$.

\section{Conditions for EDTA-Cu formation}

In the present method, EDTA and its metal chelates must be converted into EDTA-Cu prior to assay. Fig. 3 shows examples of the conversion of representative metal chalates into EDTA- $\mathrm{Cu}$ as the function of $\mathrm{pH}$. The formation of EDTA-Cu from EDTA-Ca was achieved below pH 8.0 (Fig. 3). However, $\mathrm{pH}$ value below 3.0 was necessary for the conversion of $\mathrm{EDTA}^{-}$ $\mathrm{Zn}$. Table 2 shows the formation ratio of EDTA-Cu from several metal chelates. The range of metal chelates examined were limited to those expected to occur in most food sam-

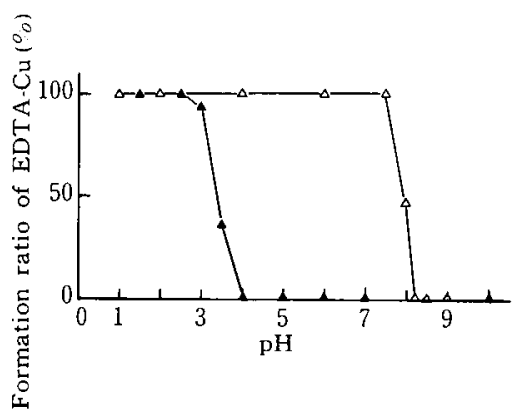

Fig. 3 Conversion of metal chelates of EDTA into EDTA-Cu as the function of $\mathrm{pH}$

$-\triangle-:$ EDTA-Ca; - $-:$ EDTA-Zn 
Table 2 Formation : ratio of EDTA-Cu from several kinds of EDTA metal chelates at $\mathrm{pH} 2.5$

\begin{tabular}{lc}
\hline $\begin{array}{l}\text { Kind of EDTA } \\
\text { metal chelate }\end{array}$ & $\begin{array}{l}\text { Formation ratio of } \\
\text { EDTA-Cu }(\%)\end{array}$ \\
\hline EDTA-Sn & 99.8 \\
EDTA-Zn & 99.7 \\
EDTA-Pb & 99.6 \\
EDTA-Fe & 1.8 \\
\hline
\end{tabular}

The amount of each metal chelate used was $0.2 \mu \mathrm{mol}$.

ples. All the metal chelates examined could be converted into EDTA-Cu, with exception of EDTA-Fe. It was shown that EDTA-Fe has a stability constant higher than that of EDTA$\mathrm{Cu}^{4}$ ). This may account for the little conversion of EDTA-Fe into EDTA-Cu. Thus, it is recommended that EDTA-Cu formation should be done below $\mathrm{pH} 3.0$. Once the metal chelates were converted into $\mathrm{EDTA}-\mathrm{Cu}$, the reverse reaction could not take place even when $\mathrm{pH}$ was brought to about 7.0 with potassium phosphate buffer. This aspect is beneficial to the present method, in which the assay of free $\mathrm{Cu}^{2+}$ was carried out at pH 7.0. We previously reported that EDTA-Fe was recovered as EDTA-2 Na through dissociation when dialysis was carried out at $\mathrm{pH}$ value above $12^{5)}$. In the present method, dialysis of the sample as the extraction procedure was done above $\mathrm{pH} 12$. Accordingly, EDTA-Fe could be determined by the present method even if this chelate remained unchanged at the EDTA-Cu formation step (Table 2).

\section{Recovery test}

The utility of the present method was tested in 16 samples of 4 kinds of foods. EDTA was added to each food at levels of 50 and $250 \mu \mathrm{g} / \mathrm{g}$ as its calcium disodium salt. The food samples were then analyzed according to the method described in Materials and Method, the results being presented in Table 3. Recovery of EDTA from mayonnaise and salad dressing were appreciably lower than those from other food samples, as is obvious from Table 3 . Thus, the recovery of EDTA is dependent on the food to be analyzed. Food samples examined were
Table 3 Recovery of EDTA from several foods

\begin{tabular}{lrc}
\hline Food & \multicolumn{1}{c}{ Added $(\mu \mathrm{g} / \mathrm{g})$} & Recovery* $(\%)$ \\
\hline Mayonnaise & 50 & $89.2 \pm 5.4$ \\
Salad dressing & 250 & $93.4 \pm 4.8$ \\
(separate type) & 50 & $88.7 \pm 6.1$ \\
Canned crab meat & 250 & $92.7 \pm 5.7$ \\
& 50 & $99.4 \pm 3.9$ \\
Canned bamboo & 250 & $99.6 \pm 3.7$ \\
shoot & 50 & $98.8 \pm 5.2$ \\
\end{tabular}

* Data represent mean value and standard deviation of four trials.

EDTA as its calcium disodium salt was added to each food indicated.

found to contain no EDTA (data not shown).

Interfering substances in foods

An attempt was made to evaluate the interference of some food ingredients on the present method. The interfering substances examined were limited to their possible ranges in foods examined. Such organic acids as citric, tartaric and oxalic did not interfere with the present method even at levels in excess of $1 \%(\mathrm{w} / \mathrm{w})$. Amino acids (glycine, glutamic acid) and peptide (glycylglycine) were also without interferences at levels of $0.01 \%(\mathrm{w} / \mathrm{w})$. Gallic acid, a class of phenolic compounds, did not affect the present method at levels of $0.01 \%(\mathrm{w} / \mathrm{w})$. These results may be ascribed to the fact that $\mathrm{Cu}^{2+}$ shows a preference of EDTA to these compounds examined with respect to complex formation. When assay of EDTA was directly applied to real sample such as mayonnaise, rich in protein and emulsifying agents, the value obtained was less than one-tenth of the added level $(50 \mu \mathrm{g} / \mathrm{g})$. This may be due to the formation of $\mathrm{Cu}^{2+}$-protein complex and/or to emulsification of the reaction mixture. The use of equilibrium dialysis at the extraction step could effectively eliminate their interferences, as is obvious from the results in Table 3 . Thus, an important feature of the present method is that extraction of EDTA is performed by using equilibrium dialysis, which allows some interfering substances such as proteins and emul- 
sifying agents to be removed.

\section{References}

1) Mihara, M., Amano, R., Kondo, T. and TANABE, H. : J. Food Hyg. Soc. Jpn, 11, 88 (1970).

2) Perfetri, G.A. and Warner, C.R.: J. Assoc. Off. Anal. Chem., 62, 1092 (1979).

3) Banick, W.M. and Smith, G.F.: Anal. Chim. Acta, 16, 464 (1957).

4) Sakaguchi, T. and Ueno, K.: Metal chelates, III. (Nankodo, Tokyo), p. 36 (1967).

5) Hamano, T., Mitsuhashi, Y., Tanaka, K., Matsuki, Y., Tonogai, Y., Nakamura, K. and Iro, Y.: J. Food Hyg. Soc. Jpn, 26, 630 (1985).

(Received Nov. 8, 1986)

\section{食品中のエチレンジアミン四酶酸の比色定量}

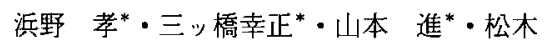
幸夫 ${ }^{*}$ 外海泰秀 ${ }^{* *} \cdot$ 中村恵三 ${ }^{* *} \cdot$ 伊藤誉志男 ${ }^{*}$
*神戸市環境保健研究所（干 650 神戸市山央区港島 中町 4-6)

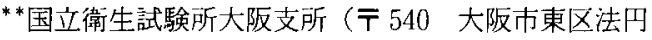
坂 1-1-43)

本報では，食品中のエチレンジアミン四酢酸（EDTA） とその金属キレートの定量法について報告する，定量法 の原理は，一定の条件下で，銅イオン $\left(\mathrm{Cu}^{2+}\right)$ はバソ クプロインと反応するが EDTA-Cu は反応しないとと

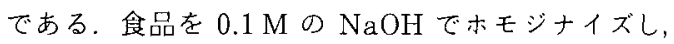
$0.02 \mathrm{M}$ の $\mathrm{NaOH}$ に対し透析する。透析液の一定量に， 既知量の $\mathrm{CuSO}_{4}$ を加え $\mathrm{pH} 2.5$ で EDTA およびその 金属キレートをEDTA-Cu に变換する，その後，溶液 を2等分し，一方を遊離 $\mathrm{Cu}^{2+}$ の測定に供する。すう一 方を $\mathrm{EDTA}-\mathrm{Cu}$ を含め総 $\mathrm{Cu}^{2+}$ の測定に供する. EDTA 量は, 総 $\mathrm{Cu}^{2+}$ より得られた吸光度 $(477 \mathrm{~nm})$ 上り遊 離 $\mathrm{Cu}^{2+}$ 上り得られた吸光度を差し引いた值から検量線 より求める. 数種の食品に添加した EDTA-Ca の回収

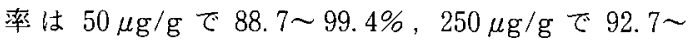
99. $9 \%$ であった。有機酸, アミノ酸, ペプ手ド, 蛋白 質および乳化剤などは，本定量法を妨害しなかった。 